\title{
Monitoring Potato Tuber Moth, Phthorimaea Operculella (Zeller), on Seed Potato at Farmers DLS and Potato Farms of Different districts of Shoa, oromia; Ethiopia
}

\author{
Tilahun, Mola; Garuma, Nemera; Mekonen, Haile
}

\author{
EIAR, Holetta Agricultural Research Center P.O. Box 31, Holetta, Ethiopia.
}

Article No.:102918053

Type: Research

DOI: 10.15580/GJAS.2018.11.102918053

Submitted: 29/10/2018

Accepted: 10/11/2018

Published: 03/12/2018

${ }^{*}$ Corresponding Author

Tilahun Mola

E-mail: tilahun235@gmail.com ; ot0235@yahoo.com

Keywords: Phthorimaea operculella; PTM, DLS, infestation, Gudene, Menagesha, Belete, Jalene, Crop rotation; internal quarantine; lower temperature
This study provides information on the highest infestation of potato tuber moth, Phthorimaea operculella, in potato fields and in storage of different weredas in Showa, Oromia, Ethiopia. Intensive survey has been done to monitor PTM at larval stage populations and tuber damage symptom from 2015 to 2017 cropping seasons. The combined data show that the maximum infestation was at shashemene $78 \%$ and the minimum was from Jeldu $(<1 \%)$ as observed at DLS condition in terms of tuber damage. Even though the infestation was low at DLS, it does not mean the same at field condition because we have got field infestation of about $15 \%$ on stem damage and $16 \%$ on leaf damage. The distribution of released potato variety at farmer's level in selected weredas has been checked; at Jeldu wereda variety Belete, Gudene, Jalene and Menagesha. But at Dendi and Degem, farmers have only two varieties as option; so intervention work should be necessary at two weredas. In terms of the infestation level at Jeldu, the highest record was from variety Gudene followed by Jalene and that with the least infestation were from variety Menagesha. Comparing PTM Infestation in terms of leaf and stem damage, regardless of variety and location (wereda) PTM, larvae prefer leaf than stem if palatable leaf is available. Thus, PTM moths emerged from pupae of infested potato tubers that were harvested from the field and stored in DLS as a source to the next planting season. Therefore, removal and destruction of all infested tubers; Crop rotation using non host crops and fallowing could reduce infestation. The ideal seed source for potato in any variety is Jeldu followed by Welmera and Degem. It is clear that internal quarantine is not only the concern of the regulatory body assigned by the government but also all of us. Now a days cold store practice is a recent way of storage but PTM can stand at lower temperature than the tubers and as such it would never be in danger of being killed by freezing and also, it is hard to have this storage capacity at local farmers and even at farmers' union level. So it is better to seek other management option at DLS for small scale farmers. Farmers leave their potatoes in the ground until the skin is hardened. This practice improves tuber storage quality and reduces spoilage, but it delays the harvest and increases normally the chance of tuber exposure to moth infestation. 


\section{INTRODUCTION}

In Ethiopia, currently the production and utilization of potato as staple food and side dish are increasing with the availability of research that developed high yielding varieties. The number of improved potato cultivars getting in to the production system has been on the increase. In order to secure the access and wider dissemination of these improved potato cultivars; small scale farmers' cooperatives and private seed multipliers were engaged in potato seed production through the assistance of National Potato Improvement program and different NGOs like CIP USAID. These producers have constructed their own diffused light seed storage (DLS) from locally available construction materials. However, the safety of this storage for insect pest infestation was not known very well. Among the major production constraints of the crop are, the bacterial wilt, early and late blight disease of potato followed by potato tuber moth (Bekele K., 2016).

The first mention of tuber moth in literature was made by Capt. H. Berthon (1855) who described it, under the name of the potato grub, as a pest very damaging to potatoes in Tasmania in 1854. He concluded that it was probably the same insect which had caused so much trouble in New Zealand in previous years. The first recognized technical description of the species was made by Zeller in 1873 from specimens collected in Texas, USA (Graf, 1917). The potato tuber moth is a pest of many solanaceous crops besides potato. Potato tuber moth (PTM) has been reported to infest other solanaceous plants such as tomato, pepper, eggplant, tobacco, and nightshade (Langford, 1934). The insect is commonly found in tropical and subtropical regions throughout the world. In Ethiopia, it has established itself as an important pest in major potato growing areas. For the last two decades, the major insect pests of potato did not differ and include: cutworms (Agrotis spp. and Exigua spp.), red ants (Dorylus sp.), potato epilachna (Epilachna hirta), metallic leaf beetle (Lagria vilosa), potato aphid (Macrosiphum euphorbiae), green peach aphid (Myzus persicae) and the potato tuber moth (Phthorimaea operculella(Zeller)). Among these insects, the potato tuber moth (PTM) received more attention than all the other potato insect pests combined. Lately, the red ants and aphids have received some attention (Ferdu, A. et al, 2009).

The importance of the pest is expected to increase because of the long distance movement of seed tubers to many places across the country from limited source locations mainly in the cool highlands of North and West Shoa (Ferdu, A. et al, 2009). Adhanom and Tesema (1981) have recorded $74 \%$ tuber infestation by the PTM on potato seeds stored for six months at Melkasa. Similarly, Bayeh and Tadesse (1992) found the insect infestation to be high in store potatoes at the highlands around Holeta. The population of PTM in DLS was monitored at Holetta Research Center from 1988-91 using sex pheromone baited traps. The insect was found to be active and common all the year round. However, the count in July was significantly higher than in the other months. This was due to the length of storage period whereby the tubers in DLS were kept for about six months after harvest (Bayeh and Tadesse, 1992). The observation also showed that DLS stored with infested seed tubers are potential source of infestation of PTM for the next crop season. Larvae of this species mine leaves, stems, and petioles and excavate tunnels through potato tubers.

Adequate control of PTM is critical because larval infestation of tubers renders potatoes unmarketable. There is zero tolerance for the presence of tuber moth larvae in raw processing product because they are classified as foreign material. In addition to that, the infested tubers rot in storage and could not be used as a seed source. Increased PTM pressure in stores has a direct implication on the multiplication and spread of the insect pest in the field. Currently, the cool highlands in the central Ethiopia are gaining country wide importance as source of improved potato seed. Therefore, in order to ensure the spread of PTM free potato seeds to different parts of the country from these sources; it was found important to monitor the PTM in DLS and at field condition of small scale seed producing farmers.

The information obtained from this study will help us to detect highest infestation level and to device management options to contain the spread of PTM to new and PTM free Areas. The objective of this study was to monitor the PTM situation in DLS and at field conditions by small scale farmers and seed growers.

\section{MATERIALS AND METHOD}

Five major potato growing Wereda; Degem, Dendi, Juldu, Shashemene and Wolmera were considered in the monitoring program (below graph 1). Maximum Five and minimum one DLS and ten farmers' field were considered per Wereda. The selection procedures were based on the current operational situation of the DLS and the farmers' engagement or experience as a model seed producer in the area. Data on the number of tubers infested out of 50 randomly picked tubers per shelf were investigated; on these tubers, the number of damaged sprouts and the number of active PTM tunnels per tuber were counted. For field infestation monitoring, 50 randomly selected plants were assessed for mines of larvae on leaves, stems, and petioles and the excavated tunnels through potato tubers. 


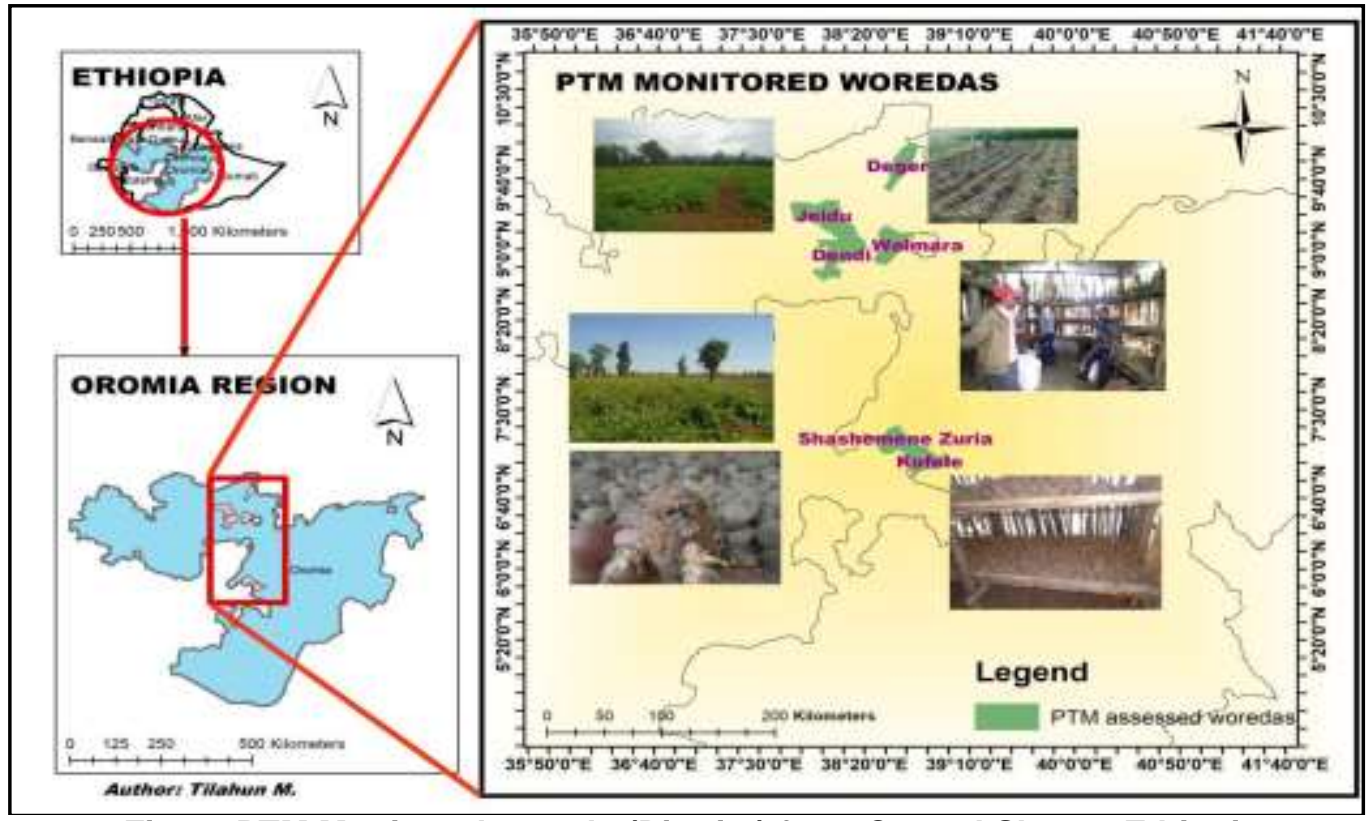

Fig. 1: PTM Monitored wereda (District) from Central Shewa, Ethiopia

\section{Data analysis}

The data were summarized per Wereda both in DLS and at field condition and one-way ANOVA was run after the data were transformed to proportions on the percentage of damaged tubers per randomly selected 50 tubers and the number of active hole per tuber. The field data were summarized in terms of mines on leaf and stem from randomly sampled plants from each farmer's field.

\section{RESULT AND DISCUSSION}

In Degem, Dendi, Jeldu, shashemene and Wolmera 10, 9, 12, 11 and 13, respectively DLSs' were picked for the monitoring. The data were collected from potato growing a total of 20 Kebeles. In each selected DLS, the number of shelves filled with seed potato tuber was recorded. The minimum number of shelves per DLS was two and that of maximum was eight shelves per Diffused light store
(DLS). In order to minimize sprout damage during the sampling process, on each shelf, only 50 tubers were randomly picked and examined carefully. On each randomly selected tuber, the number of healthy and damaged tubers by PTM larvae and the number of active PTM hole per tuber were counted. These data were collected approximately 30, 60 and 90 days after harvest. The infestation of seed tubers was found to be significantly higher in DLS in shashemene, Degem, and Dendi followed by Wolmera. There were no obvious damages in tubers in DLS in Jeldu Woredas (Fig 2). Among the damaged tubers in the samples, again a significantly higher number of them had an active PTM hole, which was identified by the accumulation of fresh excrement pushed out by the feeding larvae from their feeding galleries (fig 3). Seed tuber production has longer history, about 20 and 10 years, in Welmera and Jeldu, respectively whereas; in Dandi and Degem it is several years old according to Bayeh Mulatu. 


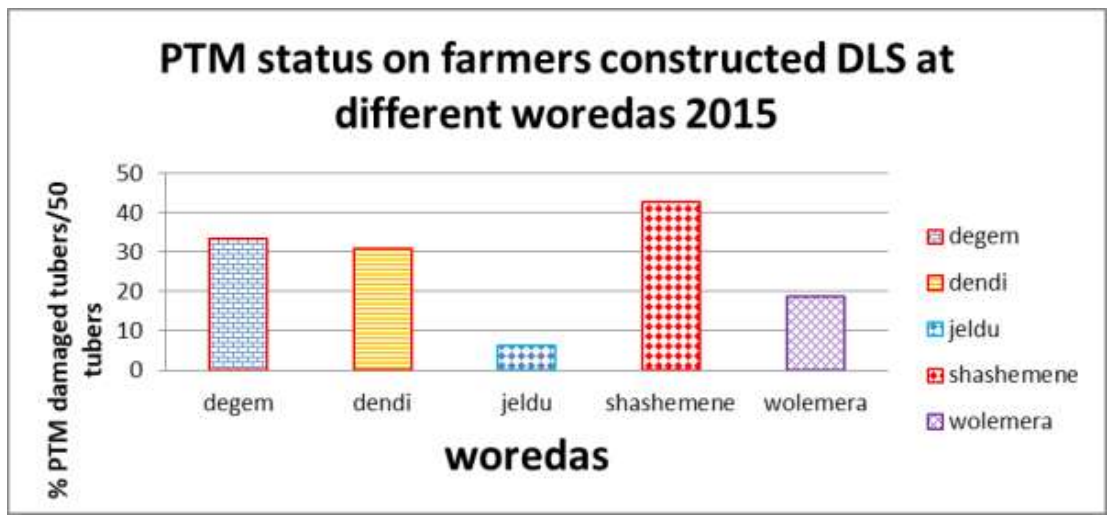

Fig. 2: The Potato tuber moth infestation at major seed producing weredas at DLS condition 2016/17

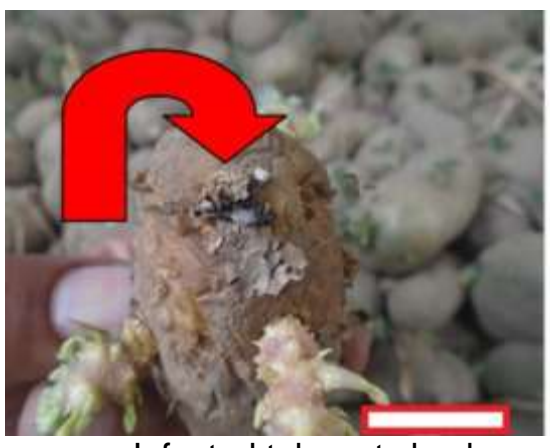

a. Infested tuber at shashemene

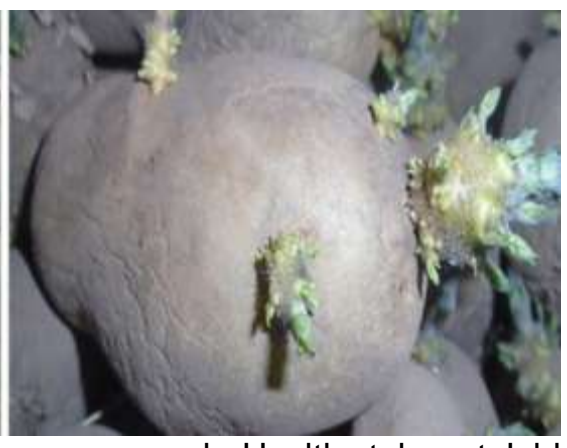

b. Healthy tuber at Jeldu

Fig. 3: a\&b. Damaged and Healthy tuber at different weredas farmers DLS

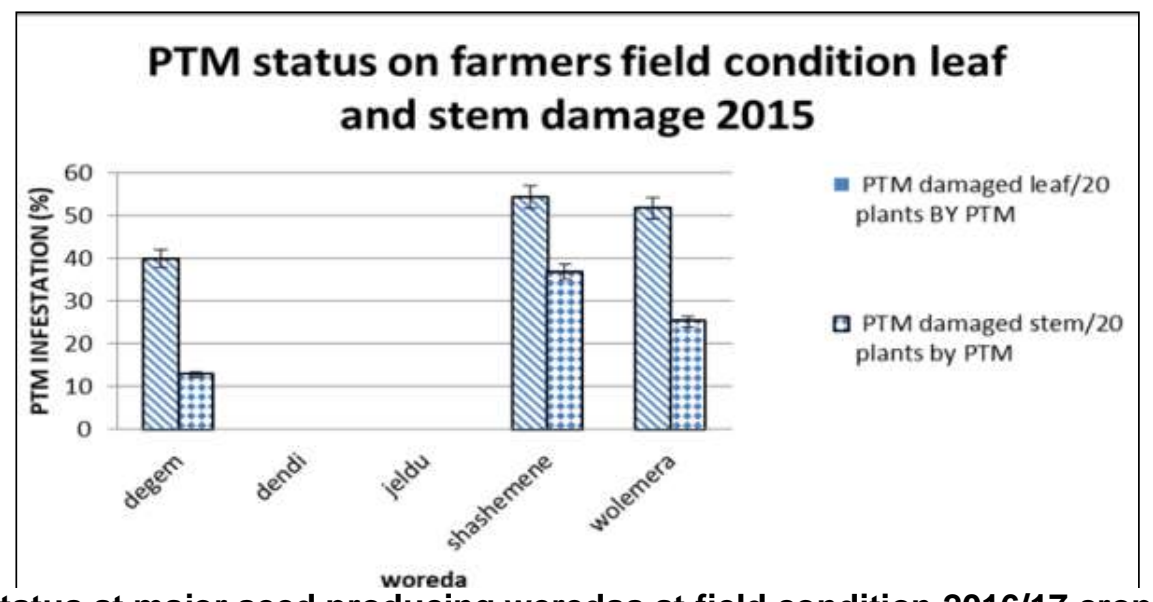

Fig. 4: PTM status at major seed producing weredas at field condition 2016/17 cropping seasons

Potato tuber moth infestations at field condition data were collected from a total of 120 farmer's potato field from five weredas and the infestation level was high in shashemene followed by walmara and Degem wereda in terms of damaged leaf and stem per plant. This shows that farmers are planting already infested tuber as seed sources for themselves and they also sell for other neighboring weredas even for far regions like Harare and Tigray as they told us. Now a days, potato seed production at different areas is facing challenges regarding quality and also quantity. As we know, potato facing disease problems especially bacterial wilt and also PTM is becoming a major insect pest in different potato producing areas both at field and DLS condition. But seed producers and some model farmers are not considering this hot issues during seed internal exchange (internal quarantine); they only focus on what they gain from this business. Infected or infested and healthy seed tubers are packed from a sack with minimal sorting (Pic. 1).

The dissemination of these major biotic problems of potato from one seed source to many new 
directions of the country, which have no previous history of infestation was unknowingly or might be have been deliberate. Once these pests have been introduced to a new area, they can survive in any environmental conditions. Even though the infestation of PTM was minimal at Dendi and Jeldu weredas, it is true that the area is known by its low Temperature and high rainfall receiving areas, due to this; the larvae may face challenge to survive and change to different larval instars at field but according to fig. 2 the problem was almost similar to highly infested weredas at Dendi and less at Jeldu.
Even though the field infestations level were less at Dendi and Jeldu, it is true that farmers should treat and manage the potato tuber immediately after harvest and store at clean, treated DLS shelves in order to sustain the purity of the seed system. A number of trainings have been given for local farmers and seed producers on potato seed production and pest management for the last two decades by agricultural experts, researchers and NGOs to build the capacity of seed producers but these days, the quality of potato seed system is decreasing from time to time at the farmers' level.

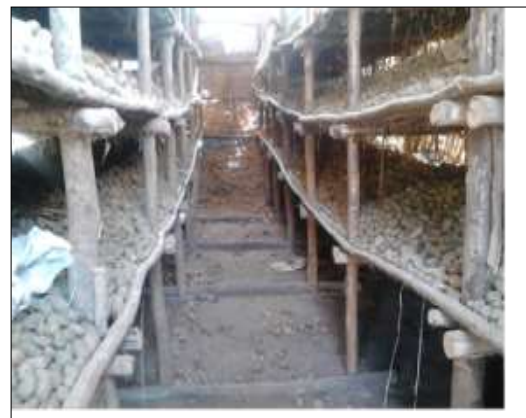

a. DLS@ shashemene.

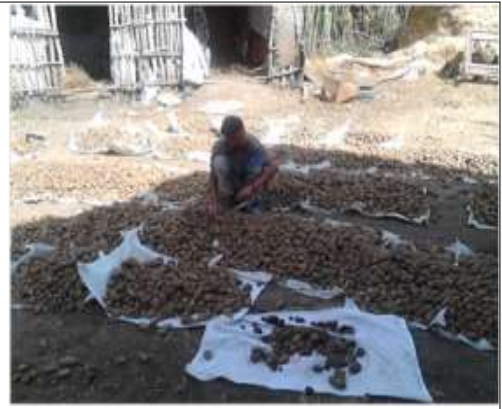

b. Seed Sorting for Market.

Pic. 1: Potato seed storage (DLS) and preparation for market for different regions

According to Bayeh Mulatu, 2004 monitoring report a few years back, he stated (fig $5 \mathrm{a} \& \mathrm{~b}$ below) that with the passing of time, the PTM pressure could also buildup in the two Woredas (Dendi and Degem) where there was no apparent PTM damage in seed potato stores. In contrast, at Walmara, the results obtained showed that there need to be initiated an active program of PTM management in DLS put up in the Wereda. Now a days, his prediction was confirmed in 2016/17 cropping seasons not more than five years. In general, these results indicate that PTM could become a threat in diffused light stores following the increase in the production of seed tubers and the number of DLS that will be put up by more small holding farmers that may join the existing seed potato producers.

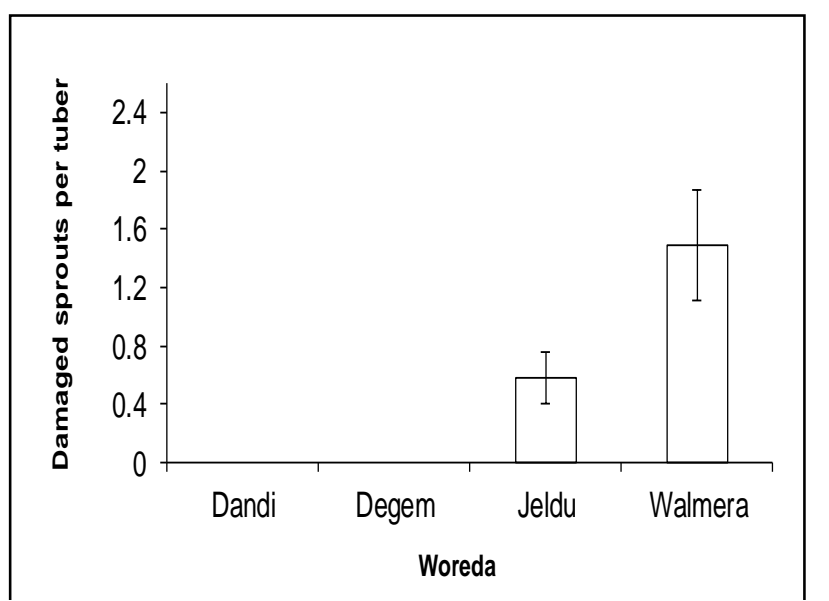

Fig. 5a: Mean \pm SE number of PTM damaged sprouts per tuber in farmer built DLS

During monitoring both at field and DLS conditions, informal communications have been done with farmers

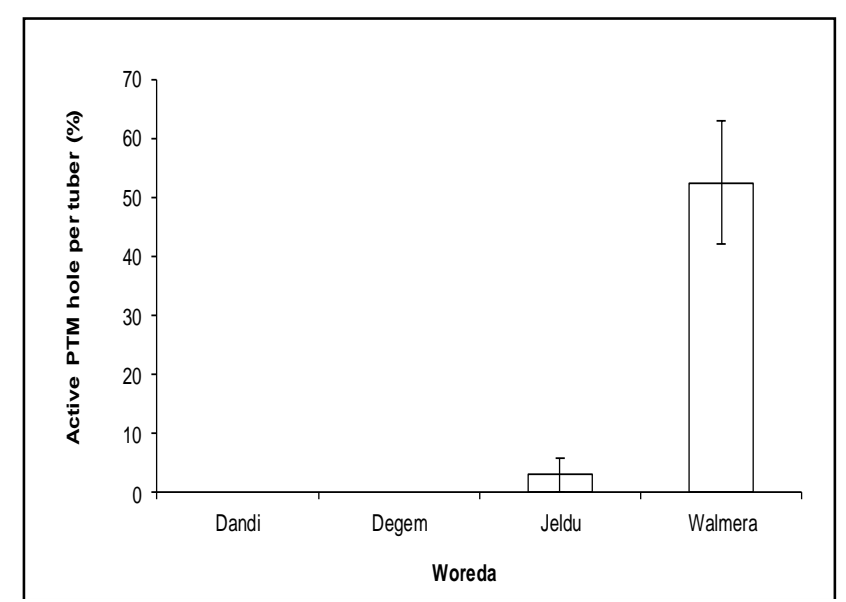

Fig. 5b: Mean \pm SE percent active PTM created hole per tuber recorded in the four Woredas

about PTM cultural management option. In different weredas, farmers practices insect pest management 
mostly using synthetic chemicals above or below the level of recommendation and also without confirming specific chemical for specific insect pests. These problems were common almost in all monitored weredas at farmer's level. At shashemene wereda, specifically Bulcha Dunba Kebele farmer Teshite Debaba stores seed tuber by covering using grass and dried eucalyptus leaf mixed with tuber. It is extremely important to harvest tubers as soon as possible after they have matured. Farmers leave their potatoes in the ground until the skin is hardened. This practice improves tuber storage quality and reduces spoilage, but it delays the harvest and increases normally the chance of tuber exposure to moth infestation.
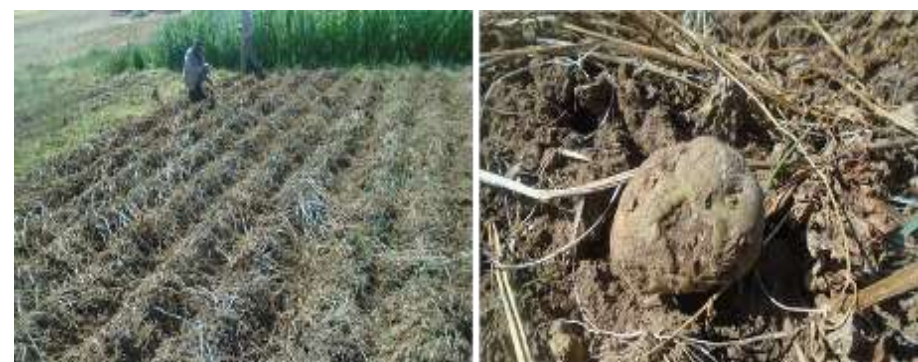

Pic. 2: Un-harvested potato for one to two months on the field as storage method but tuber damage started already on the field at sheno Degem

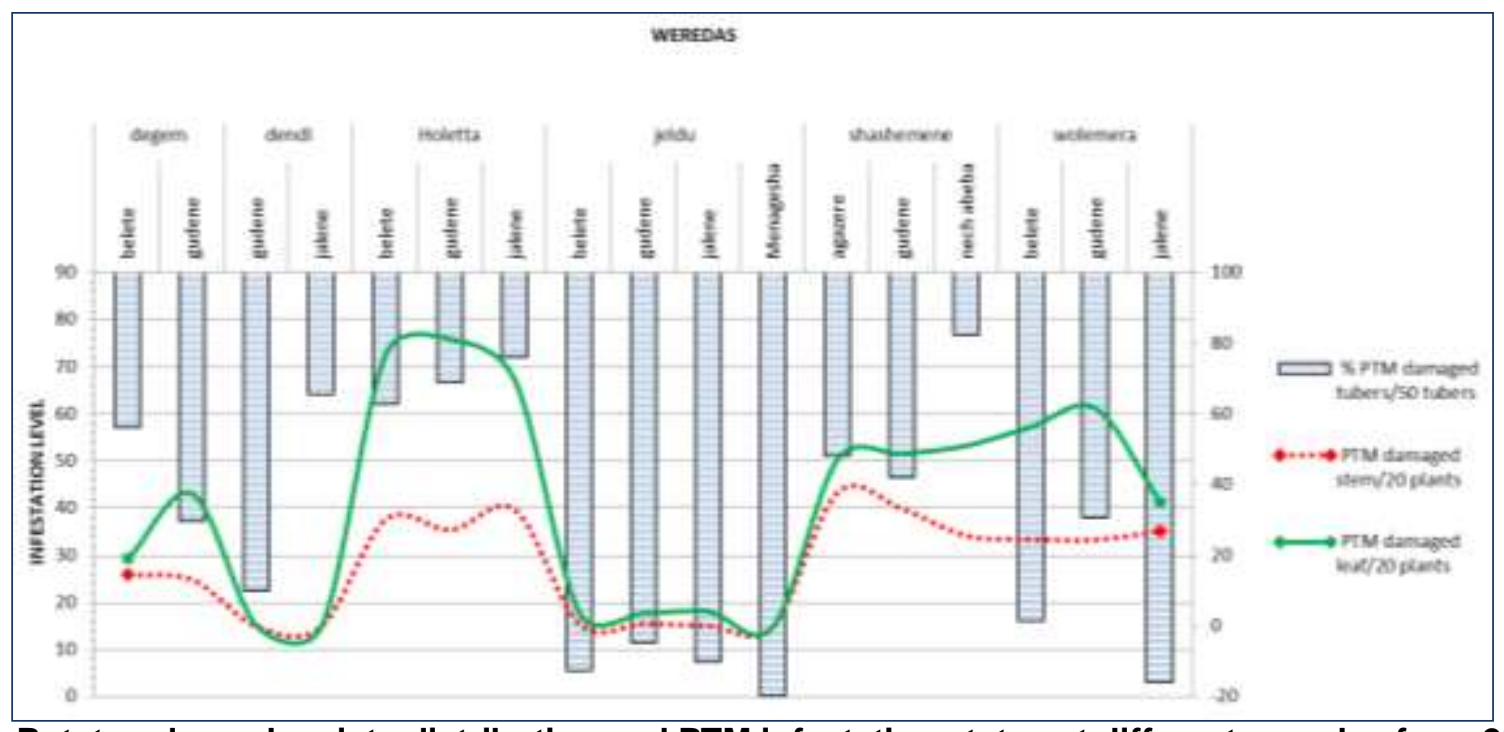

Graph 1: Potato released variety distribution and PTM infestation status at different weredas from 2015/2017

During Monitoring, we tried to see the distribution of released potato varieties at the farmer's level in selected weredas. According to graph 1, Jeldu wereda farmers plant and use seed sources from variety Belete, Gudene, Jalene and Menagesha. The least PTM infestation level also recorded from Jeldu wereda. In terms of infestation level, at Jeldu the highest record was from variety Gudene followed by Jalene and the least was from variety Menagesha. Recently released Belete Variety showed somewhat intermediate response compared to the other released varieties at Jeldu but not in other monitored weredas. Comparing PTM infestation in terms of leaf and stem damage regardless of variety and location (wereda) PTM, Phthorimaea operculella (Zeller), larvae prefer leaf than stem if palatable leaf is available. According to Rondon et al. 2007 report, potato foliage is preferred by $P$. operculella compared with the tubers. Even though Holetta area is known by its cold air condition, the PTM infestation level in terms of leaf, stem and tuber damage were significantly comparable with other known locations like shashemene and Welmera as well as Degem wereda.

\section{Potato Production Problems raised by Farmers}

In cropping systems of different agro-ecology of Ethiopia, farmers raise questions on specific crops and in general cropping systems. As we know each crop has its challenge and opportunities during production for specific purpose. During monitoring on farmers DLS and potato farms, farmers frequently ask to give a solution to different potato production constraints as we also 
observe on selected farms and DLS. I have been asked to prioritize major production problems but they do not want to list this problem as a priority. So according to farmers' responses, we have listed some important issues raised by contacted farmers from all monitored weredas as shown in table 1 below.

Table 1: Problems, Purpose and Opportunities for Potato Production at Selected Farmers

\begin{tabular}{|c|c|c|c|}
\hline No. & Problems of potato production & $\begin{array}{l}\text { Purpose of } \\
\text { Production }\end{array}$ & Opportunities for Potato Production \\
\hline 1 & Lack of pure seed of improved variety & Seed & Availability of production Packages \\
\hline 2 & Fertilizer and seed scarcity & Market & Access to farmers Association(union) \\
\hline $\begin{array}{l}3 \\
4\end{array}$ & $\begin{array}{l}\text { Cost of chemical } \\
\text { Cost of fertilizer }\end{array}$ & Food & $\begin{array}{l}\text { Model farmers } \\
\text { Favorable climate for Potato }\end{array}$ \\
\hline 5 & Disease(late blight, Bacterial wilt, Rust) & & Access to Improved seed \\
\hline 6 & Market Problem & & \\
\hline 7 & Red Ant problem at DLS & & \\
\hline 8 & Frost attack & & \\
\hline 9 & $\begin{array}{l}\text { Un able to differentiate PTM from other } \\
\text { pest problem }\end{array}$ & & \\
\hline
\end{tabular}

\section{CONCLUSION AND RECOMMENDATION}

As we know the Biology and Ecology of Potato Tuber Moth: Thus PTM moths emerged from pupae of infested potato tubers that were harvested from the field and stored in DLS were as a source to the next planting season. Therefore, removal and destruction of all infested tubers of the previous season is likely a good IPM practice to reduce $P$. operculella infestation of potatoes in subsequent cropping seasons. Crop rotation using non host crops or fallowing could also reduce infestation of potatoes; following three planting seasons in which the farm land was fallowed recommended in Senegal. According to Different literatures, the host range of $P$. operculella is wide and includes several other solanaceous species. And ideal seed source for potato in any variety is Jeldu followed by Welmera and Degem. For us, using seed from infested areas is aggravating the PTM problem and distributing to other un-infested areas in Ethiopia. It is clear that internal quarantine is not only a concern of regulatory body assigned by the government but also all of us who say the issue of potato is main; so, we have to stand against seed sources of infested by PTM, and any other potato seed quality related problems in order to defend the sustainability of potato in Ethiopia. Even though the field infestation level were less at Dendi and Jeldu it is true that farmers should treat and manage the potato tuber immediately after harvest and store at clean, treated DLS shelves in order to sustain the purity of the seed system.

Use of cold storage for potato seeds has been th practice here in Holetta Agricultural Research Center for the last two years in order to terminate the life cycle of PTM by storing potato seed between $0^{\circ} \mathrm{C}$ to $4^{\circ} \mathrm{C}$. Tuber moth can be introduced easily from one locality to another since tubers provide enough food for its multiplication and sustenance. This insect can stand lower temperature than the tubers and as such it would never be in danger of being killed by freezing. Even though a cold store can minimize the damage at storage condition it is hard for local farmers to have this storage capacity and even at farmers' union level. So it is better to seek other management option at DLS for small holder farmers. In order to block the life cycle of PTM, never plant seed tubers infested with tuber moth. PTM infested tubers should be discarded. Healthy seed tubers should be planted slightly deeper (> $10 \mathrm{~cm})$ than the conventional planting depth of $5 \mathrm{~cm}$. It is extremely important to harvest tubers as soon as possible after they have matured. PTM population dynamic studies shows that the importance of timely harvest avoid PTM infestations, which increases sharply near crop maturity. Farmers leave their potatoes in the ground until the skin is hardened. This practice improves tuber storage quality and reduces spoilage, but it delays the harvest and increases normally the chance of tuber exposure to moth infestation (Pic 2.).

\section{ACKNOWLEDGMENTS}

We would like to acknowledge Holetta agricultural Research Center; especially Horticulture research program for their facility and material support. Our sincere and heart-full gratitude goes to Mr. Wami Hailu for devoting much of his time during field work and also data collection to achieve our mission. We thank the farmers who allowed us to work on their land. The work 
was financially supported by the Ethiopian Institute of Agricultural Research.

\section{REFERENCE}

Adhanom Negasie and T Megenasa, 1981. Chemical control of the potato tuber moth. Phthorimaea operculella Zeller. (Lepidoptera: Gelechiidae) on stored potato. Ethiop J Agric Sci, 3: 105- 112.

Bayeh Mulatu and T Geberemrdhin, 1992. Studies on insect pest of potato. In E.Herath and Lemma Debano SJ, Hamm PB, Jensen A, Rondon SI, Landolt PJ. 2010. Spatial and temporal dynamics of the potato tuberworm (Lepidoptera: Gelechiidae) in the Columbia Basin of the Pacific Northwest. Environ Entomol. 39(1):1-14.

Bayeh Mulatu and Tadesse Gebremedhin. 1992. Pest of potato in Ethiopia. pp 202-208 In: Heras and Lemma (eds.): Proceedings of the $2^{\text {nd }}$ Horticultural Workshop Dec 1-3 1992, Addis Ababa, Ethiopia.

Berthon, H., 1855. On the potato grub of Tasmania. In Papers \& Proceedings of the Royal Society of Tasmania (Vol. 3, No. 1, pp. 76-79).

Dessalegne (eds.) Horticulture research and development in Ethiopia. Proceedings of the second national horticultural workshop of Ethiopia, 1-3 Dec 1992. Addis Ababa Ethiopia.

Ferdu, A., Bayeh, M., Emana, G., Temesgen, A., Eyob, T., Messele, G. and Brook, W., 2009. Review of entomological research on root and tuber crops in Ethiopia. Abraham Tadesse. Increasing crop production through improved plant protection, 2, pp.1-45.

Gubbaiah, Thontadarya TA. 1977. Bionomics of potato tuber worm, Gnorimoschema operculella Zeller (Lepidoptera:Gelechiidae) in Karnataka. Mysore J Agric Sci.11:380-386.

Graf, J.E., 1917. The potato tuber moth (No. 427). US Department of Agriculture.

Kassa, B., 2016. Potato bacterial wilt management in the Central Highlands of Ethiopia. Ethiopian Journal of Agricultural Sciences, 26(2), pp.83-97.

Langford GS, 1934. Winter survival of the potato tuber moth, Phthorimaea operculella Zeller. J Econ Entomol, 27: 210-213.

Rondon SI, Debano SJ, Clough GH, Hamm PB, Jensen A, Schreiber A, Alvarez JM, Thornton M, Barbour J, Dŏgramaci M. 2007. Biology and management of the potato tuber worm in the Pacific Northwest.Pacific Northwest Extension Publishing. http://extension.oregonstate.edu/catalog/pdf/ pnw/pnw594. 8 pp.

Trivedi TP, Rajagopal D. 1992. Distribution, biology, ecology and management of potato tuber moth Phthorimaea operculella (Zeller) Lepidoptera: Gelechiidae): a review. Trop Pest Manag. 38(3):279285. 